\title{
Extrafloral nectaries of annatto (Bixa orellana L.): anatomy, nectar composition and activity during organ development
}

\author{
Rafaela Marques de Miranda', Lays Araújo Nery' and Marilia Contin Ventrella' ${ }^{\star *}$
}

Received: May 16, 2017

Accepted: June 14, 2017

\begin{abstract}
This study aimed to anatomically characterize the extrafloral nectaries (EFNs) of annatto (Bixa orellana) and determine the composition of its nectar in order to better understand their structure and function during organ development. Standard light and scanning electron microscopy techniques were used for anatomical analysis, and test-strips and a refractometer for determining nectar composition. Both receptacle and stem EFNs were found to possess similar anatomy and nectar composition, and to secrete from early to advanced developmental stages of the organs to which they are associated. EFNs consisting of uniseriate epidermis, nectariferous parenchyma and subnectariferous parenchyma were found located where vascular tissue is immersed. Some layers of nectariferous parenchyma exhibited sclerification and cells with phenolic compounds or calcium oxalate druses were present. Nectar exuded by stomata was acidic, diluted and found to contain sugar. The anatomical and histochemical features of annatto EFNs ensure their integrity and nectar secretion function during the development of buds, flowers and fruits.
\end{abstract}

Keywords: ants, histochemistry, nectar release, secretory structure, urucum

\section{Introduction}

Annatto (Bixa orellana) is widely known for possessing the reddish pigment bixin in its seed coats. In addition to folk uses by different populations in South America, where the species is native, the red pigment has been widely used as a natural dye by the food, cosmetic and pharmaceutical industries (Hakuno 2005).

Bixa orellana is the most well known species of the family Bixaceae. Among the anatomical characters considered diagnostic for the family, the presence of different secretory structures, such as extrafloral nectaries (EFNs), mucilage canals and bixin secretory structures, stand out in $B$. orellana (Solereder 1908; Metcalfe \& Chalk 1957; 1983; 1988). Extrafloral nectaries located on the receptacle and stems have ecophysiological implications, including involvement in interactions with other organisms and the reproductive success of the species (Bentley 1977b). Nonetheless, these EFNs have yet to be studied from an anatomical and histochemical point of view. There are many similarities among EFNs independent of the taxonomic relationship of the taxa upon which they occur, but some particularities can exist depending on their ecological function, such as variation in the morphoanatomy and chemical composition of the secreted nectar (Nepi 2007). The shape, size, vascularization, mode of accumulation and release of secretion, presence of calcium oxalate crystals and secondary compounds, and the chemical composition of nectar, among others, are morphoanatomical and chemical characteristics that are known to vary and are relate to the

\footnotetext{
${ }^{1}$ Laboratório de Anatomia Vegetal, Departamento de Biologia Vegetal, Universidade Federal de Viçosa, 36570-009, Viçosa, MG, Brazil

*Corresponding author: ventrella@ufv.br
} 
functionality of EFNs (Fahn 1979; Elias 1983; Nepi 2007).

Aspects of the ecology and function of EFNs of annatto were studied by Bentley (1977b), but without an anatomical approach that to establish relationships between structure and function. The extrafloral nectaries of annatto are associated with protective activity by ants against possible bud, flower and fruit predators (Bentley 1977b). Nectaries located on stems and the floral receptacle of annatto can be considered EFNs from a functional point of view (Elias 1983; Pacini \& Nicolson 2007). They are extranuptial because they are not related to pollination (Bentley 1977a), since anthesis lasts only one day, while secretory activity occurs for a considerably longer period of time (Bentley 1977b).

The objective of the present work was to anatomically characterize the EFNs of annatto, to analyze the histochemistry of the secretion and to determine nectar composition during the development of buds, flowers and fruits in order to clarify structural and chemical attributes that may be related to nectar secretion and visitation by ants.

\section{Materials and methods}

\section{Plant material and collection area}

Extrafloral nectaries of annatto (Bixa orellana) were collected from receptacles of floral buds, flowers and fruits, and from stems associated with leaves at different stages of development. Plants were cultivated in the Botanical Garden of the Department of Plant Biology of the Federal University of Viçosa (UFV), in Viçosa, Minas Gerais, Brazil. A voucher specimen was deposited in the Herbarium of Federal University of Viçosa (VIC), under No. 31977. Receptacle EFNs were collected from reproductive organs at five different developmental stages (Fig. 1) equivalent to those proposed by Bentley (1977b): a) young buds (sepals fully covering the petals since their emergence in the buds); b) pre-anthesis or mature buds (partially exposed petals); c) flower in anthesis; d) young fruit (two days after anthesis); and e) developing fruit (seven days after anthesis). Stem EFNs were collected from nodes with leaves at four different stages of development: a) young leaf (protected by stipules); b) expanding leaf; c) completely expanded leaf; and d) senescent leaf (presenting chlorotic and necrotic regions).

\section{Light microscopy}

For anatomical and histochemical analysis, the EFNs used were fresh or fixed in formalin and ferrous sulfate (Johansen 1940), for the preservation of phenolic compounds, or fixed in Karnovsky (Karnovsky 1965) for 48 hours and stored in $70 \%$ ethanol (Johansen 1940), for general histological analysis. Fixed samples were dehydrated in an increasing ethanol series and embedded in methacrylate (Historesin, Leica, Heidelberg, Germany) according to Paiva et al. (2011). Cross and longitudinal sections cut at $5-\mu \mathrm{m}$ thick using a rotary microtome (model RM2155, Leica Microsystems Inc., Deerfield, USA) were stained with toluidine blue O, pH 4.4 (O'Brien et al. 1964) and mounted under a coverslip with synthetic resin (Permount, Fisher Scientific, Pittsburgh, USA). For histochemical tests some of the material fixed in Karnovsky and embedded in methacrylate was subjected to periodic acid/reagent Shiff (PAS) (McManus 1948) for the detection of polysaccharides. Samples of fresh material sectioned on a table microtome (LPC, Rolemberg e Bhering Comércio e Importação Ltda, Belo Horizonte, Brazil) were stained with sudan scarlet red (Brundrett et al. 1991) for identifying lipids, Wagner reagent (Furr \& Mahlberg 1981) for alkaloids, acid phloroglucin (Johansen 1940) for lignin, ferric chloride (Johansen 1940) for phenolic compounds and hydrochloric vanillin (Johansen 1940) for tannins. Except for the acid phloroglucin test, all tests were also applied to drops of secretion.

The observation and capture of images were carried out using a digital camera (model Spot Insightcolour 3.2.0, Diagnostic Instruments, New York, USA) coupled in a photomicroscope (model AX70 TRF, Olympus Optical, Tokyo, Japan).

\section{Scanning electron microscopy}

For micromorphological characterization of EFNs, samples were fixed in $\mathrm{FAA}_{50}$ for 48 hours and stored in 70
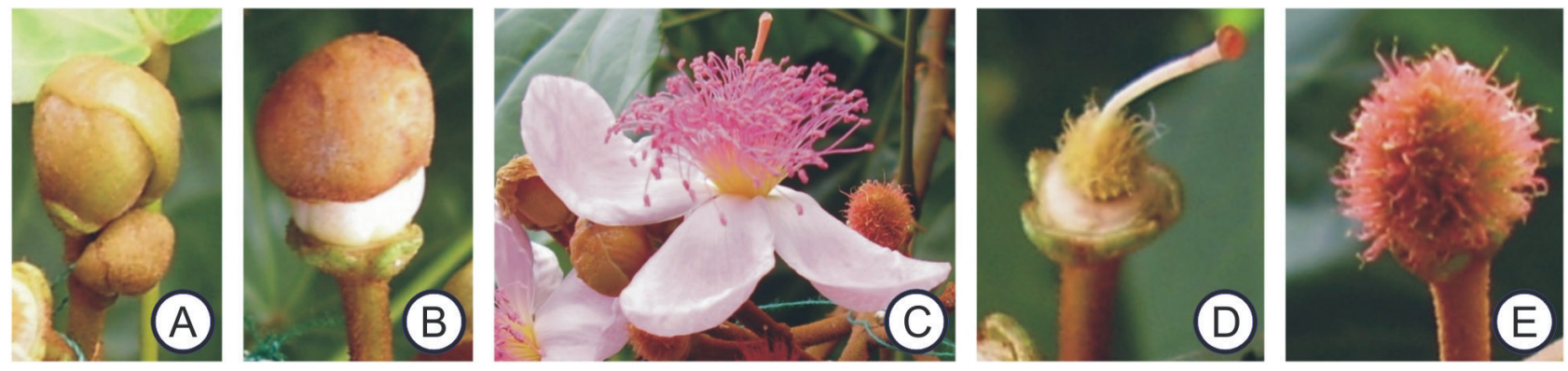

Figure 1. Annatto receptacle EFNs in different stages of floral development. A. young buds. B. pre-anthesis buds with partially exposed petals. C. flower in anthesis. D-E. developing fruit with 2 (D) and 7 days (E). 
$\%$ ethanol (Johansen 1940). The samples were dehydrated in an ethylic series, dried to critical point with $\mathrm{CO}_{2}$ (equipment model CPD 020, Bal-Tec, Balzers, Liechtenstein), attached to stubs with double-sided tape, and coated with gold (equipment Sputter Coater, model FDU 010, Bal-Tec, Balzers, Liechtenstein). The observation and the capture of images were carried out using a scanning electron microscope (model Zeiss, LEO 1430 VP, Cambridge, England).

\section{Nectar collection and analysis}

Vegetative branches with flowers and with developing fruit (ten of each) were collected and placed in buckets with water. The branches and buckets were protected with transparent plastic bags and kept for 12 hours in the laboratory in order to facilitate the collection of nectar yet minimizing evaporation. The nectar was collected with the aid of a capillary in order to calculate the volume secreted by each EFN. Test-strips (Combur ${ }^{10}$ Test $^{\circledR}$ UX - Roche) were used to determine $\mathrm{pH}$ and quantify nitrites, proteins and glucose. The amount of soluble solids (Brix\%) was measured using a manual refractometer (Atago CO, Ltd, Japan).

\section{Results}

\section{Distribution and morphology}

There are five EFNs present in each receptacle of floral buds, flowers and fruits in development, which are conspicuous, rounded in shape, greenish with small red spots (Fig. 2A-L), glabrous in the central region and bordered by scamiform trichomes. Stem EFNs occur in pairs at nodes and are located immediately below the scar left by the abscission of the stipules (Fig. 3A-C). The EFNs present in the stem are morphologically similar to those present in the receptacle, but are less conspicuous, more rounded and flatter in the central portion.

\section{Anatomy}

Receptacle and stem EFNs are characterized by having uniseriate epidermis, nectariferous parenchyma and vascularized subnectariferous parenchyma (Fig. 2D-E). In the central region, the epidermis is composed of ordinary cuboidal cells with thick and non-lignified external periclinal walls, and stomata located at the same level as the other epidermal cells; in the peripheral region stomata are scarcer and there are peltate trichomes (Figs. 2F-L, 3D-E). The cuticle is impregnated along the external periclinal walls and part of the anticlinal walls of the epidermal cells (Fig. $4 \mathrm{~A}$ ). No secretion accumulates in the subcuticular space and nectar release occurs through stomatal pores, which are constantly open after differentiation (Fig. 2L). Both the ordinary epidermal cells and the peltate trichomes have phenolic content. All the underlying nectariferous parenchyma possesses isodiametric cells with chloroplasts, which gives a greenish color to the EFNs (Fig. 4B-C). Bixinsecreting structures are present throughout the nectariferous parenchyma, and produce small reddish spots on the surface of EFNs (Fig. 4B-F). Calcium oxalate druses are present in the nectariferous parenchyma cells (Fig. 2G-H). The first layers of the nectariferous parenchyma are composed of cells with thickened and lignified walls and with a large amount of phenolic compounds, whereas the underlying layers possess only cells with thin and non-lignified walls (Fig. $4 \mathrm{D}-\mathrm{F}$ ). The subnectariferous parenchyma consists of thinwalled and more vacuolated and achlorophyllous cells, which may contain phenolic compounds (Fig. 2D-E) or druses of calcium oxalate near the phloem, where exceptionally some chloroplasts can be found. Mucilage secretory canals also occur in the subnectariferous parenchyma (Fig. 2D). The vascular tissue borders the nectariferous parenchyma and crosses the entire subnectariferous parenchyma. Xylem and phloem are abundant, but only the phloem is inserted in the more peripheral layers of nectariferous parenchyma.

The morphoanatomy of receptacle and stem EFNs is similar in all stages of development of the organs, but some anatomical (Figs. 1-3) and histochemical (Fig. 4, Tab. 1) variation was observed. The thickening and lignification of the cell walls of the nectariferous parenchyma (Fig. 4DF) and the opening of the stomatal pore (Fig. 2I-L) were observed only in EFNs from the pre-anthesis buds or the expanding leaf, where secretion is already conspicuous. In these stages of organ development, small starch grains accumulate in the nectariferous parenchyma cells (Fig. 4G) and larger starch grains in the subnectariferous parenchyma cells adjacent to the vascular tissue (phloem) (Fig. 4H).

\section{Secretion time and nectar composition}

Receptacle and stem EFNs secrete nectar and therefore are functional. Although all EFNs are constantly visited by ants, secretory activity depends on the stage of development of the organs (Tab. 2). Receptacle EFNs secrete nectar intensely in pre-anthesis buds, flowers and young fruits, but there is no secretion by the EFNs of young flower buds and secretion is rare in developing fruit (from seven days before the anthesis). Nectar release was also observed in some inflorescences with branches with fruits in more advanced stages of development. The EFNs located at nodes associated with young leaves (still protected by stipules) do not secrete nectar, and secretion is maximal in EFNs located on nodes with expanding and fully expanded leaves. In EFNs located at the nodes of senescent leaves the secretion is inconspicuous.

The nectar secreted by the receptacle and stem EFNs present similar characteristics, depending on the degree of development of flowers and fruits (Tab. 2). The volume of nectar ranges from 0.028 to $0.038 \mu \mathrm{L}$ per nectary, while 
Extrafloral nectaries of annatto (Bixa orellana L.):

anatomy, nectar composition and activity during organ development
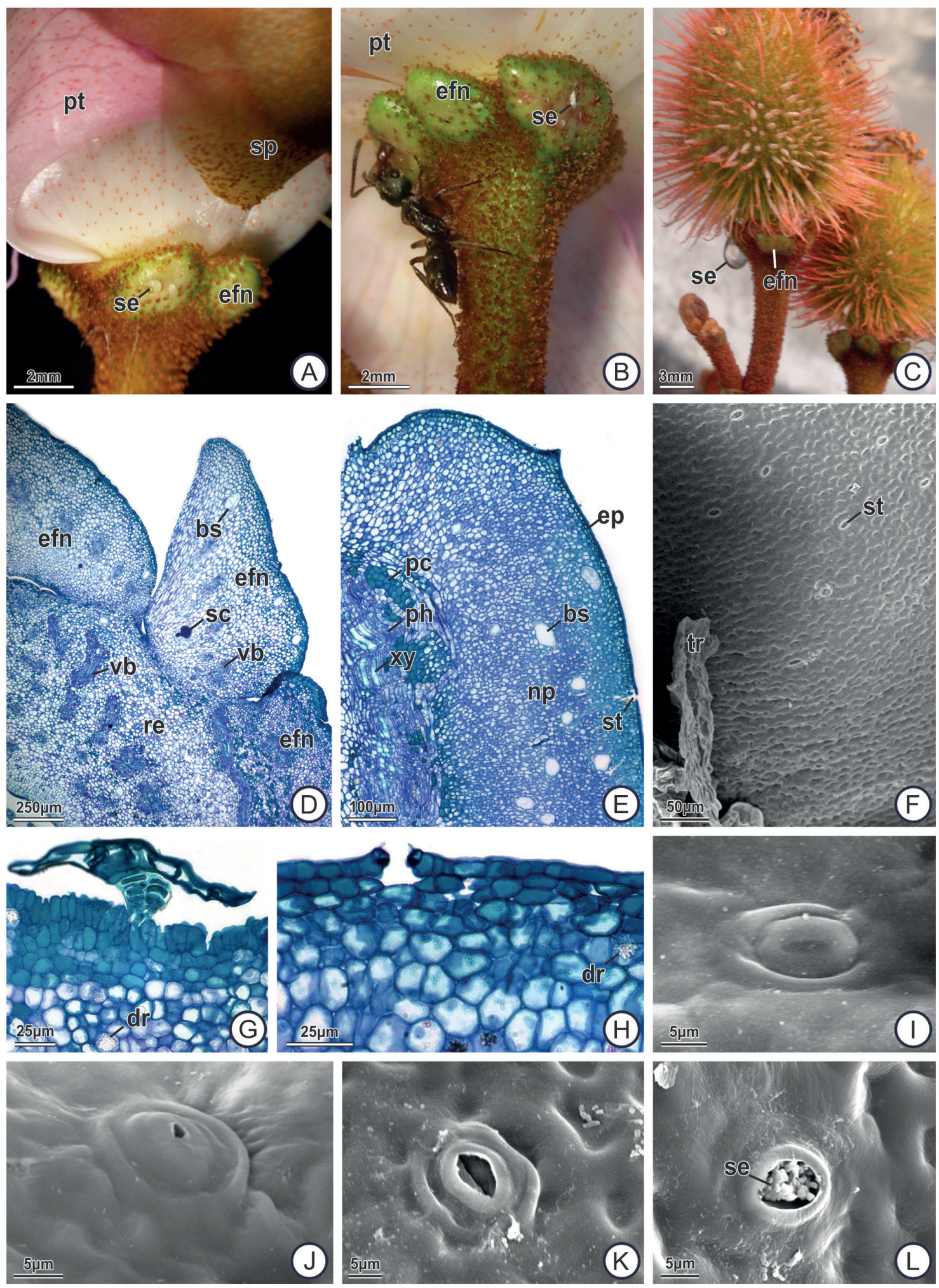

Figure 2. Annatto receptacle EFNs. A-C. stereophotomicrographs. D-E, G-H. photomicrographs. F, I-L. scanning electromicrographs. A. pre-anthesis flower. B. flower in anthesis. Note ant visitation. C. fruit in development. Arrows indicate secretion release. D. EFNs inserted externally into the floral receptacle, in cross-section. E. EFN in longitudinal section. F. surface of the EFN. G. peltate trichome. H. stomata. I-J. stomata in differentiation in flower buds. Note stomatal cristae still attached. K-L. completely differentiated stomata in flowers in pre-anthesis $(\mathrm{K})$ and anthesis (L). bs: bixin secreting structure; dr: druse of calcium oxalate; efn: extrafloral nectary; ep: epidermis; np: nectariferous parenchyma; pc: phenolic cells; pt: petal; ph: phloem; re: receptacle; se: secretion; sc: secretory canal; sp: sepal; st: stomata; tr: trichome; vb: vascular bundle; xy: xylem. 

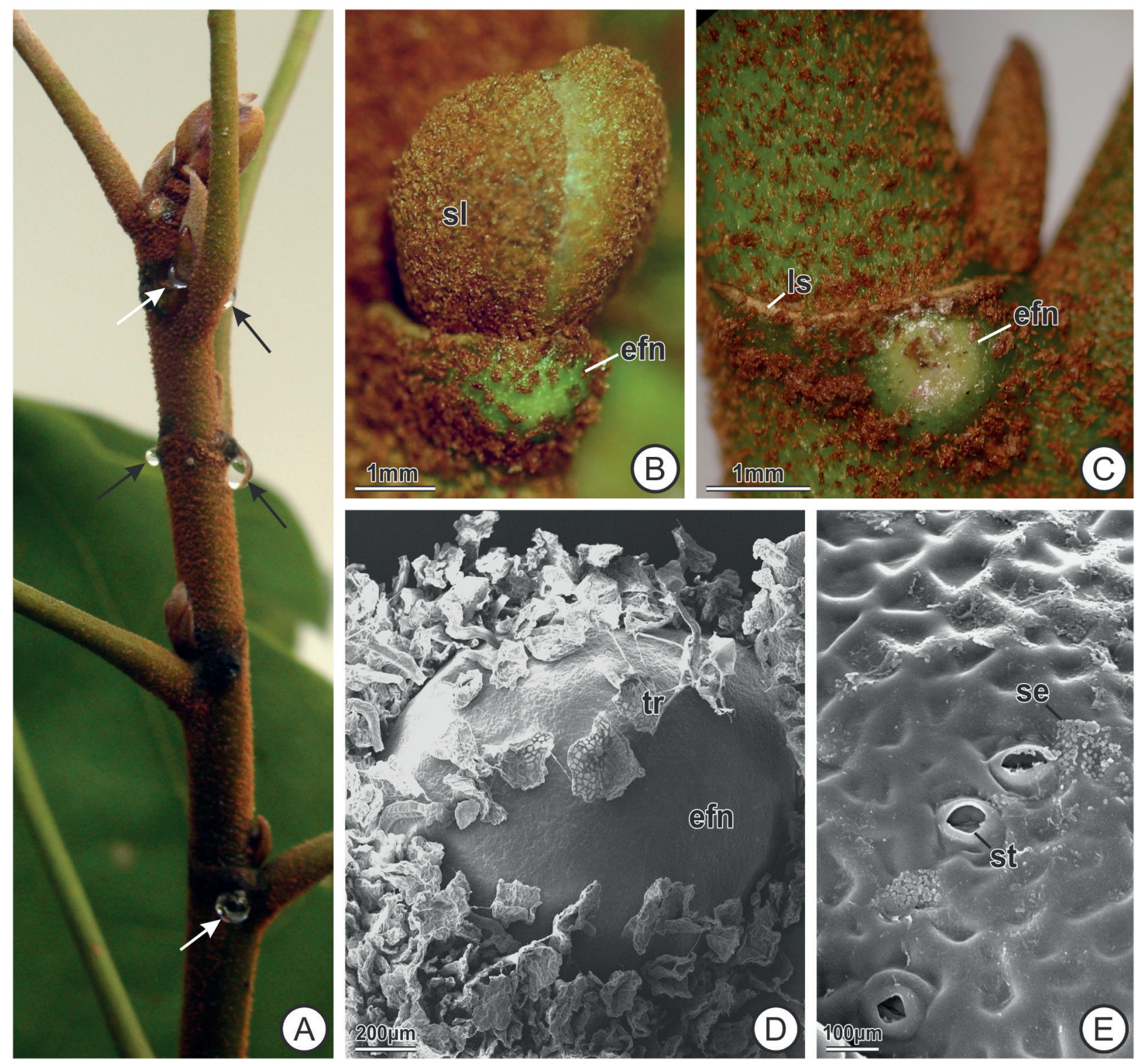

Figure 3. Annatto stem EFNs. A. general view of branch. Arrows indicate secretion. B-C. stereophotomicrographs. D-E. Scanning electromicrographs. B, D. Developing EFNs associated with protective leaf primordia stipule. C, E. differentiated EFNs associated with young leaf. efn: extrafloral nectary; ls: leaf scar; se: secretion; sl: stipule; st: stomata; tr: trichome.

the soluble solids content ( ${ }^{\circ}$ Brix) ranges from 9.5 to $13.8 \%$. In all EFNs analyzed, the nectar is acidic ( $\mathrm{pH} 5.0$ ), has a glucose content higher than $1000 \mathrm{mg} \cdot \mathrm{dL}^{-1}$ and lacks nitrites, proteins, lipids, alkaloids and phenolic compounds (Tab. 1).

\section{Discussion}

The location and morphology of EFNs in receptacles and stems of annatto are similar to those found by Bentley (1977b) and are typical EFNs (Fahn 1979; Nepi 2007). The general anatomical aspects of annatto EFNs are common to nectaries of representatives of different botanical families such as Triumfetta semitriloba - Tiliaceae (Leitão et al. 2005), Hymenaea stigonocarpa - Fabaceae (Paiva \& Machado 2006), Cedrela fissilis - Meliaceae (Paiva et al. 2007), Prockia crucis - Salicaceae (Thadeo et al. 2008), Passiflora amethystina Passifloraceae (Rocha et al. 2009) and Sapium biglandulosum - Euphorbiaceae (Coutinho et al. 2010), but yet possess peculiar anatomical, physiological and ecological attributes.

Nectar produced by the annatto EFNs is released through stomata and spreads as a continuous liquid layer. The stomata involved in nectar release are modified and the guard cells usually lose their ability to close and open (Fahn 1979; Nepi 2007). Remarkably, when annatto EFNs become active in expanding leaves and in flower buds in 
Extrafloral nectaries of annatto (Bixa orellana L.):

anatomy, nectar composition and activity during organ development

Table 1. Histochemical tests applied to extrafloral nectaries (EFNs) of annatto.

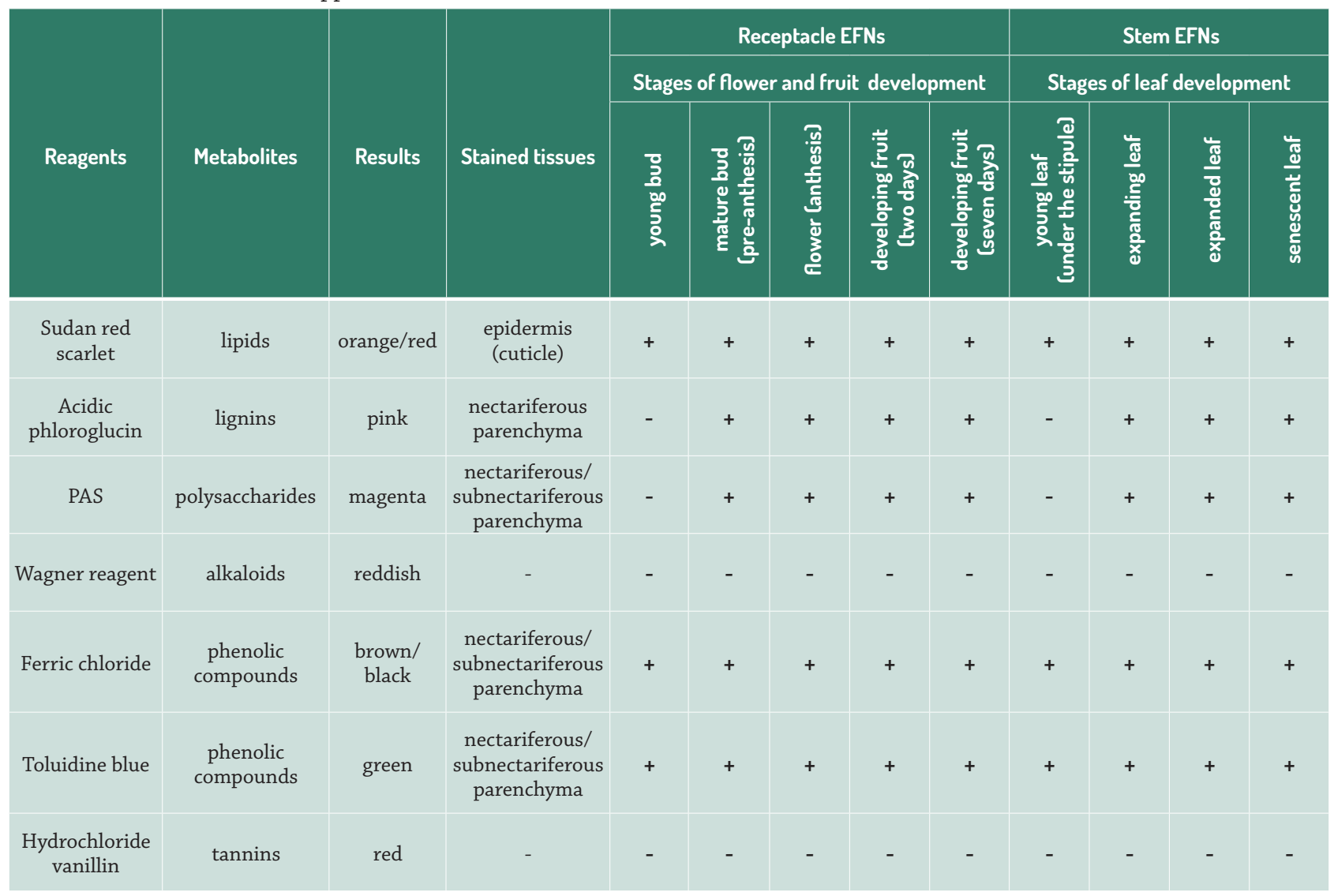

Table 2. Composition of the nectar secreted by extrafloral nectaries (EFNs) of annatto.

\begin{tabular}{|c|c|c|c|c|c|c|c|}
\hline Organ with EFNs & Phases of development & $\begin{array}{l}\text { Volume/ } \\
\text { EFN }(\mu L)\end{array}$ & $\mathrm{pH}$ & Nitrite & $\begin{array}{l}\text { Protein } \\
\text { [mg.dL-1] }\end{array}$ & $\begin{array}{l}\text { Glucose } \\
\text { [mg.dL-1] }\end{array}$ & ${ }^{\circ}$ Brix $[\%]$ \\
\hline \multirow{2}{*}{ Receptacle } & Flowers (anthesis) & 0.031 & 5 & - & - & $\geq 1000$ & 9.8 \\
\hline & Developing fruits & 0.033 & 5 & - & - & $\geq 1000$ & 13.0 \\
\hline \multirow{3}{*}{ Stem } & With flower buds and flowers & 0.031 & 5 & - & - & $\geq 1000$ & 9.5 \\
\hline & With fruits & 0.038 & 5 & - & - & $\geq 1000$ & 9.6 \\
\hline & Without flowers / fruits & 0.028 & 5 & - & - & $\geq 1000$ & 13.8 \\
\hline
\end{tabular}

pre-anthesis, the stomata invariably possess a fully open ostiole. It is interesting to note that the secretion of nectar by stomata is more common in floral nectaries (FNs), as observed in Ecballium elaterium (Fahn \& Shimony 2001), Glycine max (Horner et al. 2003), Ipomoea species (Galetto \& Bernardello 2004), Echinacea purpurea (Wist \& Davis 2006), Ocimum basilicum (Mačukanović-Jocić et al. 2007), Hymenaea stigonocarpa (Paiva \& Machado 2008) and Tontelea micrantha (Mercadante-Simões \& Paiva 2016), among other species. Extrafloral nectaries of various families eliminate the nectar predominantly by cuticular rupture or via microchannels of the cuticle (Paiva \& Machado 2006; Paiva et al. 2007; Thadeo et al. 2008; Rocha et al. 2009; Coutinho et al. 2010) or by trichomes (Leitão et al. 2005).

The nectariferous parenchyma of EFNs generally possesses small cells with thin cell walls (Fahn 1979; Nepi 2007), as reported for other species (Leitão et al. 2005;
Paiva \& Machado 2006; Paiva et al. 2007; Thadeo et al. 2008; Rocha et al. 2009; Coutinho et al. 2010), but in the EFNs of annatto the first layers of secretory parenchyma, underlying the epidermis, are exceptionally thickened and lignified. This sclerification in EFNs suggests an investment in mechanical protection, which would make this longterm structure more resistant to mechanical damage by foraging or predation. In addition, chemical protection of nectariferous tissues is also observed in EFNs of annatto, as also reported for in T. semitriloba (Leitão et al. 2005), $H$. stigonocarpa (Paiva \& Machado 2006), C. fissilis (Paiva et al. 2007), P. crucis (Thadeo et al. 2008), and S. biglandulosum (Coutinho et al. 2010), where nectariferous tissues possess numerous cells with phenolic content.

The nectariferous parenchyma of annatto EFNs can be classified as the photosynthesizing type (Pacini \& Nepi 2007). Therefore, the starch grains found in the nectariferous 

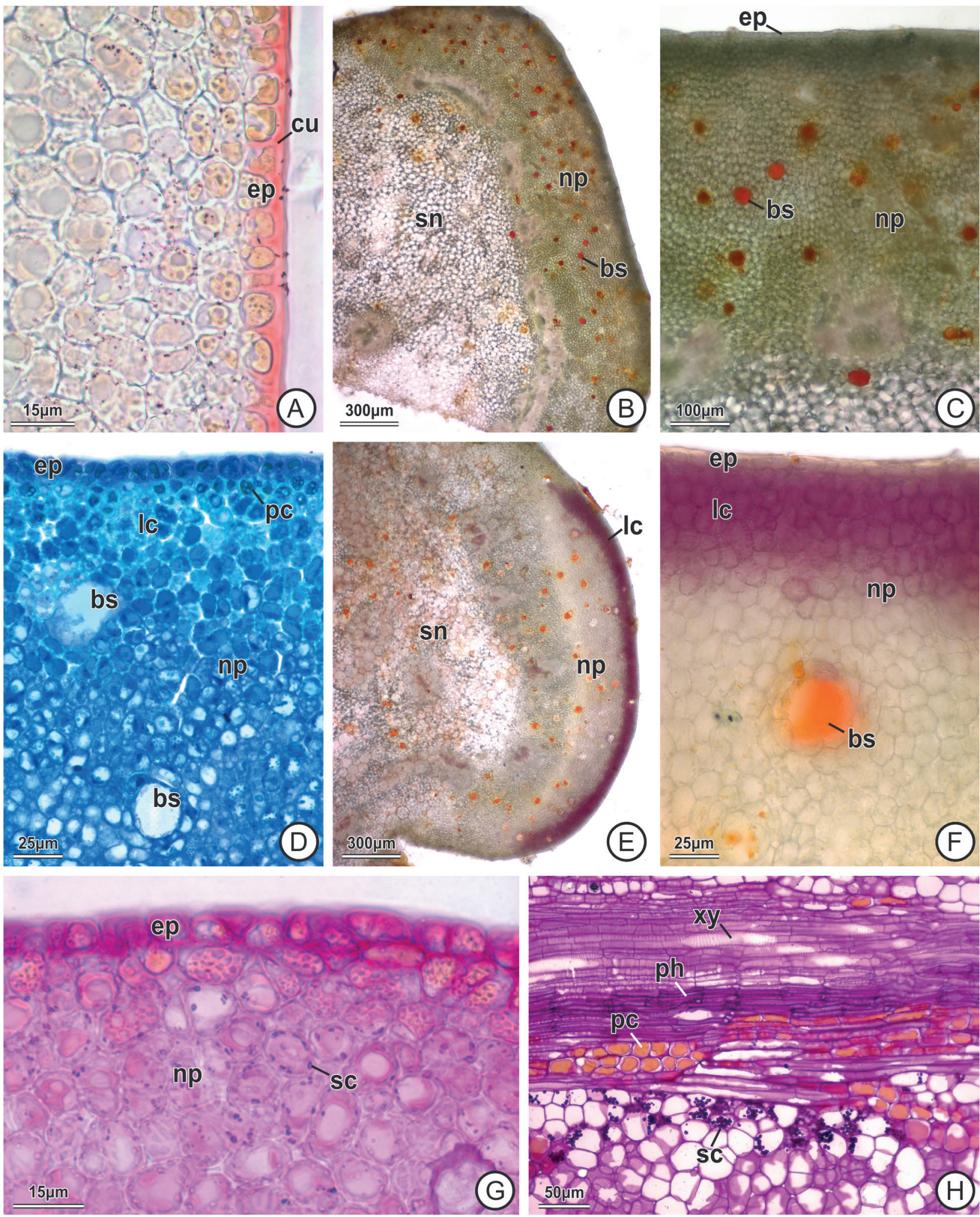

Figure 4. Histochemical tests in annatto receptacle EFNs (photomicrographs, cross sections). A. sudan scarlet red; reddish color indicates lipids. B-C. fresh material. D. toluidine blue; greenish color indicates phenolic compounds. E-F. acidic phloroglucin; reddishpink color indicates lignin. G-H. periodic acid / Schiff reagent (PAS); magenta staining indicates neutral polysaccharides. bs: bixin secreting structure; cu: cuticle; ep: epidermis; lc: lignified cells; np: nectariferous parenchyma; pc: phenolic cells; ph: phloem; sc: starch; sn: subnectariferous parenchyma; xy: xylem. 
and subnectariferous parenchyma of annatto EFNs must originate directly by photosynthesis in this tissue and stored for only a few hours to be hydrolysed at night (Pacini et al. 2003).

Calcium oxalate crystals, such as those occurring in annatto EFNs, are commonly found in EFNs (Nepi 2007), but their functions in this secretory structure are not yet fully understood. There are numerous hypotheses regarding crystal function in plants including calcium regulation, plant protection, detoxification, ion balance, tissue rigidity, and even light gathering and reflection (Franceschi \& Nakata 2005). Some of these functions have been suggested for the presence of calcium oxalide crystals in EFNs, such as the control of calcium levels due to the intense simplastic transport of nectar and its precursors in nectariferous tissues (Paiva \& Machado 2006). Tooulakou et al. (2016) recently demonstrated that calcium oxalate crystals in the mesophyll of Amaranhus hybridus can serve as sources of carbon dioxide when there is stomatal closure under drought conditions or exogenous application of abscisic acid. Under these conditions, there was crystal decomposition and increased activity of oxalate oxidase that converts oxalate into carbon dioxide. This new photosynthetic path, referred to by the authors as "alarm photosynthesis", could also occur in photosynthetic type nectariferous parenchyma of EFNs. In this way, there could be a relationship between the presence of calcium oxalate crystals and the presence of chloroplasts and, consequently, photosynthesis in nectariferous tissues. In annatto EFNs, calcium oxalate crystals are found in the nectariferous parenchyma and, eventually, in the subnectariferous parenchyma near the phloem, both of which are sites where chloroplasts and starch grains are also found. Extrafloral nectaries of $H$. stigonocarpa (Paiva \& Machado 2006), C. fissilis (Paiva et al. 2007), P. crucis (Thadeo et al. 2008), and S. biglandulosum (Coutinho et al. 2010), for example, are also greenish and contain calcium oxalate crystals in nectariferous tissues, but they do not possess stomata in the epidermis. Annatto EFNs have stomata, but from the moment ostiole are open, they are blocked by continuous secretion of nectar. The release of carbon dioxide by calcium oxalate crystals could be a way to compensate for low gas exchange in compact tissues such as EFNs and maintain the photosynthetic process.

The vascularization of EFNs is generally related to their size and composition of secreted nectar (Fahn 1979; Elias 1983; Nepi 2007). In EFNs of annatto, the vascular bundles, composed of xylem and phloem, are conspicuous and delimit the nectariferous parenchyma. Abundance of vascular tissue is probably related to the large size of EFNs (Carlquist 1969), such as in annatto, which is easily observed with the naked eye, and nectar composition. Many constituents of nectar originate in phloem sap (pre-nectar) and the water may come from both xylem and phloem or only phloem (Elias 1983; Pacini \& Nicolson 2007). Production of more diluted nectar counts on the participation of xylem for the supply of water (Pacini \& Nicolson 2007), as in annatto EFNs. Extrafloral nectaries generally secrete a small volume of nectar (a few $\mu \mathrm{L}$ per day) compared to FNs (less than $1 \mu \mathrm{L}$ to a few $\mathrm{mL}$ ), and in the latter the volume of nectar would be proportional to the volume of the nectariferous parenchyma (Pacini \& Nicolson 2007). Annatto EFNs secrete a reduced volume of nectar (0.028 to $0.038 \mu \mathrm{L}$ per EFN), although they are relatively large and with a considerable proportion of the structure occupied by the nectariferous parenchyma. However, it should be considered that the activity of FNs is ephemeral compared to the activity of EFNs.

Sugars are the major solutes of the nectar, and their total concentration ranges from $7-70 \%(w / w)$ (Pacini \& Nicolson 2007). Therefore, nectar of annatto EFNs can be considered diluted, since the content of soluble solids ( ${ }^{\circ}$ Brix) ranges from 9.5 - $13.8 \%$ during organ development. Slight variation in soluble solid content of receptacle and stem EFNs of annatto can be attributed to changes in source-sink relationships during organ development, but these data were not analyzed statistically. Quantitative variation in nectar and its composition may also be related to the method used for collecting nectar, since branches were removed from plants and bagged in the laboratory. The use of test-strips for the evaluation of nectar only allows the identification of glucose, and the maximum concentration verified by this method (1000 mg.dL $\mathrm{dL}^{-1}$ or approximately $0.1 \%$ ) falls short of that commonly found in nectar (Pacini \& Nicolson 2007). Other compounds can also be found in nectar in general, however, in the present study no proteins, lipids or secondary compounds were found that could attract or repel visitors, such as terpenoids or alkaloids, respectively (Pacini \& Nicolson 2007). The acidity (pH 5.0), small volume, high dilution of sugars and the low viscosity of the nectar of annatto EFNs lead to its presentation as a continuous layer of acidic secretion on the epidermis, and thus conducive to foraging by ants (Bentley 1977b).

The EFNs of annatto are already differentiated and functional in receptacles of mature flower buds and in stem nodes recently exposed by abscission of stipules. From the structural point of view, the onset of nectar secretion is associated with the lignification of the cell walls of the secretory parenchyma and the complete differentiation of stomata (opening of the ostiole) in the EFNs, whereby the release of the nectar occurs. From the functional point of view, the activity of annatto EFNs is established early, and is maintained until the beginning of fruit maturation (receptacle EFNs) or onset of leaf senescence (stem EFNs). It is associated with plant protection in critical phases of development in reproductive and aerial vegetative organs, as observed by Bentley (1977b). According to this author, the secretion of nectar by EFNs of annatto is constant during the 24 hours of the day and guarantees constant patrolling by ants. As a consequence of constant patrolling, there is a reduction in the activity of phytophagous insects and herbivores and, consequently, an improvement to 
the reproductive performance of the plant by increased production of fruits and seeds. In H. stigonocarpa (Paiva \& Machado 2006), C. fissilis (Paiva et al. 2007) and P. crucis (Thadeo et al. 2008), the early differentiation and secretory activity of EFNs are also related to intense ant patrol during critical phases of leaf susceptibility, thereby ensuring organ integrity. Therefore, the anatomical and histochemical characteristics of annatto EFNs ensure their integrity and continuous secretion of nectar during the development of buds, flowers, fruits and leaves, which are protected by the constant patrol of ants.

\section{Acknowledgements}

The authors thank Conselho Nacional de Desenvolvimento Científico e Tecnológico (CNPq) for granting a scholarship to RM Miranda and team of Núcleo de Mircroscopia e Microanálise (NMM-UFV) for aid in sample preparation.

\section{References}

Bentley BL. 1977a. Extrafloral nectaries and protection by pugnacious bodyguards. Annual Review of Ecological Systems 8: 407-27.

Bentley BL. 1977b. The protective function of ants visiting the extrafloral nectaries of Bixa orellana (Bixaceae). The Journal of Ecology 65: 27-38.

Brundrett MC, Kendrick B, Peterson CA. 1991. Efficient lipid staining in plant material with Sudan Red 7B or Fluoral Yellow 088 in polyethylene glycol-glycerol. Biotechnic \& Histochemistry 66: 111-116.

Carlquist S. 1969. Toward acceptable evolutionary interpretations of floral anatomy. Phytomorphology 19: 332-362.

Coutinho IAC, Valente VMM, Meira RMSA. 2010. Ontogenetic, anatomical and histochemical study of the extrafloral nectarines of Sapium biglandulosum (Euphorbiaceae). Australian Journal of Botany 58: 224-232.

Elias TS. 1983. Extrafloral nectaries: their structure and distribution. In: Bentley BL, Elias TS. (eds.) The biology of nectaries. New York, Columbia University Press. p. 174-203.

Fahn A. 1979. Secretory tissues in plants. London, Academic Press.

Fahn A, Shimony C. 2001. Nectary structure and ultrastructure of unisexual flowers of Ecballium elaterium (L.) A. Rich. (Cucurbitaceae) and their presumptive pollinators. Annals of Botany 87: 27-33.

Franceschi VR, Nakata PA. 2005. Calcium oxalate in plants: formation and function. Annual Review of Plant Biology 56: 41-71.

Furr M, Mahlberg PG. 1981. Histochemical analyses of lacticifers and glandular trichomes in Cannabis sativa. Journal of Natural Products 44: 153-159.

Galetto L, Bernardello G. 2004. Floral nectaries, nectar production dynamics and chemical composition in six Ipomoea species (Convolvulaceae) in relation to pollinators. Annals of Botany 94: 269-280.

Hakuno D. 2005. Materials. In: Prance G, Nesbitt M. (eds.) The cultural history of plants. New York, Routledge. p. 335-353.

Horner HT, Healy RA, Cervantes-Martinez T, Palmer R. 2003. Floral nectary fine structure and development in Glycine max L. (Fabaceae). International Journal of the Plant Science 164: 675-690.

Johansen DA. 1940. Plant microtechnique. New York, McGraw-Hill.
Karnovsky MJ. 1965. A formaldehyde-glutaraldehyde fixative of high osmolarity for use in electron microscopy. The Journal of Cell Biology 27: 137-138.

Leitão CAE, Meira RMSA, Azevedo AA, Araújo JM, Silva KLF, Collevatti RG. 2005. Anatomy of the floral, bract, and foliar nectaries of Triumfetta semitriloba (Tiliaceae). Canadian Journal of Botany 83: 279-286.

Mačukanović-Jocić MP, Rančić DV, Stevanović ZPD. 2007. Floral nectaries of basil (Ocimum basilicum): Morphology, anatomy and possible mode of secretion. South African Journal of Botany 73: 636-641.

McManus JFA. 1948. Histological and histochemical uses of periodic acid. Stain Technology 23: 99-108.

Mercadante-Simões MO, Paiva EAS. 2016. Anatomy and ultrastructure of the floral nectary of Tontelea micrantha (Celastraceae: Salacioideae). Plant Species Biology 31: 117-124.

Metcalfe CR, Chalk L. 1957. Anatomy of the dicotyledons: leaves, stem, and wood in relation to taxonomy with notes on economic uses. Vol. 2. Oxford, Clarendon Press.

Metcalfe CR, Chalk L. 1983. Anatomy of the dicotyledons: wood structure and conclusion of the general introduction. Vol. 2. 2nd. edn. Oxford, Clarendon Press.

Metcalfe CR, Chalk L. 1988. Anatomy of the dicotyledons: systematic anatomy of leaf and stem, with a brief history of the subject. Vol. 1. 2nd. edn. Oxford, Clarendon Press.

Nepi M. 2007. Nectary structure and ultrastructure. In: Nicolson S, Pacini E, Nepi M. (eds.) Nectaries and nectar. Dordrecht, Springer. p. 129-166.

O'Brien TP, Feder N, McCully ME. 1964. Polychromatic staining of plant cell walls by toluidine blue O. Protoplasma 59: 368-373.

Pacini E, Nepi M. 2007.Nectar production and presentation. In: Nicolson S, Pacini E, Nepi M. (eds.) Nectaries and nectar. Dordrecht, Springer. p. 167-214.

Pacini E, Nepi M, Vesprini JL. 2003. Nectar biodiversity: a short review. Plant Systematic and Evolution 238: 7-21.

Pacini E, Nicolson SW. 2007. Introduction. In: Nicolson S, Pacini E, Nepi M. (eds.) Nectaries and nectar. Dordrecht, Springer. p. 1-18.

Paiva EAS, Buono RA, Delgado MN. 2007. Distribution and structural aspects of extrafloral nectarines in Cedrela fissilis (Meliaceae). Flora 202: 455-461.

Paiva EAS, Machado SR. 2006. Ontogênese, anatomia e ultra-estrutura dos nectários extraflorais de Hymenaea stigonocarpa Mart. ex Hayne (Fabaceae-Caesalpinioideae). Acta Botanica Brasilica 20: 471-482.

Paiva EAS, Machado SR. 2008. The floral nectary of Hymenaea stigonocarpa (Fabaceae, Caesalpinioideae): structural aspects during floral development. Annals of Botany 101: 125-133.

Paiva EAS, Pinho SZ, Oliveira DMT. 2011. Large plant samples: how to process for GMA embedding? Methods in Molecular Biology 689: 37-49.

Rocha DI, Silva LC, Valente VMM, Francino DMT, Meira RMSA. 2009. Morphoanatomy and development of leaf secretory structures in Passiflora amethystina Mikan (Passifloraceae). Australian Journal of Botany 57: 619-626.

Solereder H. 1908. Systematic Anatomy of the dicotyledons: a handbook for laboratories of pure and applied botany. Vol. 2. Oxford, Clarendon Press.

Thadeo M, Cassino MF, Vitarelli NC, et al. 2008. Anatomical and histochemical characterization of extrafloral nectaries of Prockia crucis (Salicaceae). American Journal of Botany 95: 1515-1522.

Tooulakou G, Giannopoulos A, Nikolopoulos D, et al. 2016. "Alarm photosynthesis": calcium oxalate crystals as an internal $\mathrm{CO}_{2}$ source in plants. Plant Physiology 171: 2577-2585.

Wist TJ, Davis AR. 2006. Floral nectar production and nectary anatomy and ultrastructure of Echinacea purpurea (Asteraceae). Annals of Botany 97: 177-193. 